DOI: https://doi.org/10.31933/dijms.v2i6

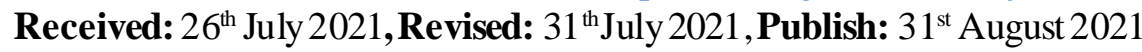

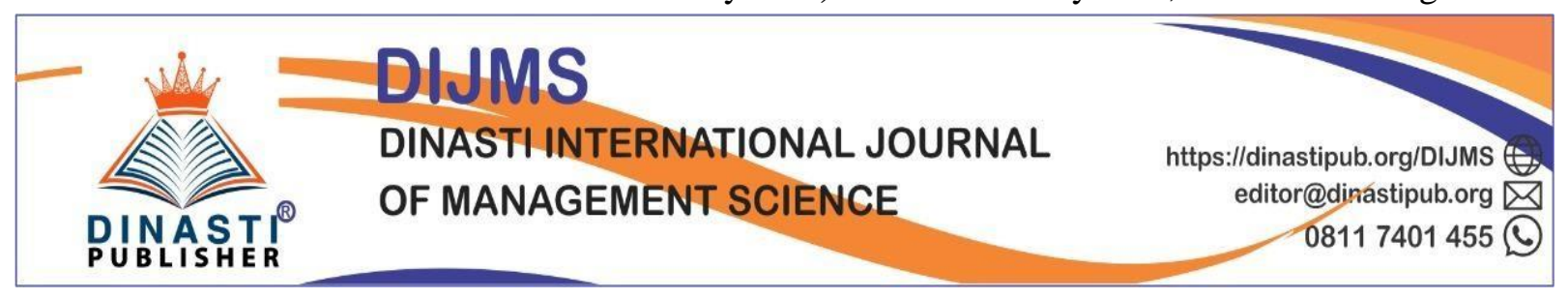

\title{
THE EFFECT OF LEADERSHIP AND MOTIVATION ON TEACHER PERFORMANCE AND WORK COMMITMENT AS INTERVENING VARIABLES (CASESTUDY AT SMK BINA PENDIDIKAN 3 BOGOR)
}

\author{
Sajum Sutisna ${ }^{1}$, Masydzulhak Djamil MZ² $^{2}$, Ali Iqbal ${ }^{3}$ \\ ${ }^{1}$ Universitas Mercu Buana, Indonesia, sutisnasajum@gmail.com \\ ${ }^{2}$ Universitas Mercu Buana, Indonesia, masydk@ gmail.com \\ ${ }^{3}$ Universitas Mercu Buana, Indonesia, ali.iqbal@ mercubuana.ac.id
}

Corresponding Author: Sajum Sutisna

\begin{abstract}
This study aims to determine the effect of leadership and motivation on teacher performance with work commitment as an intervening variable at SMK Bina Pendidikan 3 Bogor. This research uses smartPLS version 3.0 software. with the existing analysis method that is explanatory, based on the initial hypothesis that this research consists of four variables, namely, leadership, motivation, commitment and teacher performance. From the results of research with the $t$ hypothesis, the results of this study are work commitment has a positive and significant effect on teacher performance, leadership has a positive and significant effect on teacher performance, motivation has no effect on teacher performance, leadership has a positive and significant effect on work commitment, and motivation has a positive effect and significant to the work committee,
\end{abstract}

Keywords: Leadership, Motivation, Commitment and Teacher Performance

\section{INTRODUCTION}

Education is one of the basic capital to create superior human resources. The main world of education is school. Schools as a system have components that are related to each other and contribute to the achievement of the vision or goals. These components are students, curriculum, teaching materials, teachers, principals, education staff, infrastructure, learning processes and learning outcomes.

To produce superior resources, quality education must be carried out. Quality education is of course also supported by quality teachers, becau se teachers are at the forefront of the learning process to produce quality resources. One of the educational problems faced today is the low quality of education at every level and unit of education. Some of the problems that cause the low quality of education in Indonesia are the economic crisis, globalization, regional autonomy, lack of physical facilities, low quality of teachers, and low student achievement. 
A teacher is expected to have a high commitment to the organization where he works. Teachers who have a high commitment to the organization will support the achievement of the school's vision, mission, and goals in order to improve the quality of schools in particular and the quality of education in general. Teachers must have a high commitment to the organization, because with a high commitment to the organization teachers can support the achievement of the school's vision to improve the quality of service to students. The teacher's commitment to the organization is the attitude, behavior and feelings of a teacher towards the organization. The teacher's commitment to the organization includes dimensions of affective commitment, continual commitment and normative commitment.

Leaders are one of the components that have the most role in improving the quality of education, the quality of leadership in leading will be very closely related to various aspects of school life. One of the most important is teaching and learning activities. Leaders must be able to move teachers to further optimize their performance in order to achieve the goals of education that have been set as well as to improve the quality of education.

According to PP RI No. 19/2005 concerning the National Education Standard Article 28, educators are learning agents who must have four types of competencies, namely pedagogic competence, personality competence, professional competence, and social competence. In essence, teacher performance appraisal is not to make it difficult for teachers, but to create professional teachers who have a set of competencies to carry out their main tasks because the dignity of a profession is determined by the quality of quality professional services. Through the teacher performance assessment process, it is expected that the strengths and weaknesses of teachers in carrying out activities in the classroom or school can increase their knowledge and skills in accordance with the competencies required in carrying out these functions and duties.

Based on the data I collected at SMK Bina Pendidikan 3, Kanbupaten Bogor, there are phenomena regarding teacher performance which according to the author is still not going well, many teachers still have not made / collected learning tools, such as: annual program (prota), semester program (promissory note), and lesson plans. Teacher performance is mainly related to attendance during the 2018-2019 school year. I obtained the following data:

Table 1. List of Presence of Vocational Education Teachers

\begin{tabular}{|c|c|c|c|c|c|c|c|c|c|}
\hline \multirow{3}{*}{$\begin{array}{l}\mathbf{N} \\
\mathbf{0}\end{array}$} & \multirow{3}{*}{ Month } & \multicolumn{6}{|c|}{ Not present } & \multicolumn{2}{|c|}{ Percentage Score } \\
\hline & & Late & $\begin{array}{l}\text { Come } \\
\text { Home } \\
\text { Faster }\end{array}$ & $\begin{array}{c}\text { Amou } \\
\text { nt }\end{array}$ & $\begin{array}{c}\text { Conv } \\
\text { ersio } \\
\mathbf{n}\end{array}$ & $\begin{array}{c}\text { Witho } \\
\text { ut } \\
\text { explan } \\
\text { ation }\end{array}$ & $\begin{array}{c}\text { Numbe } \\
\text { r of } \\
\text { absent }\end{array}$ & $\begin{array}{c}\text { Not } \\
\text { presen } \\
\mathbf{t}\end{array}$ & present \\
\hline & & $\begin{array}{c}( \\
\text { Minute }\end{array}$ & $\begin{array}{c}\text { (Minute } \\
\text { ) }\end{array}$ & $\begin{array}{c}\text { (Minut } \\
e)\end{array}$ & $\begin{array}{c}\text { (day } \\
\text { ) }\end{array}$ & (day) & & $\%$ & $\%$ \\
\hline 1 & January & 10 & 10 & 20 & & 2 & 2.00 & 4.35 & 95.65 \\
\hline 2 & February & 15 & 5 & 20 & 0.04 & 2 & 2.04 & 4.44 & 95.56 \\
\hline
\end{tabular}




\begin{tabular}{|c|c|c|c|c|c|c|c|c|c|}
\hline 3 & March & 5 & 5 & 10 & 0.02 & 3 & 3.02 & 6.57 & 93.43 \\
\hline 4 & April & 15 & 15 & 30 & 0.07 & 2 & 2.07 & 4.49 & 95.51 \\
\hline 5 & May & 10 & 15 & 25 & 0.06 & 5 & 5.06 & 10.99 & 89.01 \\
\hline 6 & June & 8 & 10 & 18 & 0.04 & 3 & 3.04 & 6.61 & 93.39 \\
\hline 7 & July & 5 & 15 & 20 & 0.04 & 6 & 6.04 & 13.14 & 86.86 \\
\hline 8 & August & 10 & 5 & 15 & 0.03 & 2 & 2.03 & 4.42 & 95.58 \\
\hline 9 & $\begin{array}{l}\text { Septemb } \\
\text { er }\end{array}$ & 15 & 5 & 20 & 0.04 & 3 & 3.04 & 6.62 & 93.38 \\
\hline 10 & October & 15 & 15 & 30 & 0.07 & 2 & 2.07 & 4.49 & 95.51 \\
\hline 11 & $\begin{array}{l}\text { Novemb } \\
\text { er }\end{array}$ & 10 & 15 & 25 & 0.06 & 4 & 4.06 & 8.82 & 91.18 \\
\hline 12 & $\begin{array}{l}\text { Decembe } \\
\mathrm{r}\end{array}$ & 17 & 15 & 32 & 0.07 & 2 & 2.07 & 4.50 & 95.50 \\
\hline & mount & 135 & 130 & 245 & 0.54 & 36 & 36.54 & 79.44 & \\
\hline \multicolumn{9}{|c|}{ ATTENDANCE PRESENTATION INDEX } & 20.56 \\
\hline
\end{tabular}

Source: Administration of VocationalEducation Development 3

Table 2 Results of Supervision of Teacher Performance Assessment

\begin{tabular}{|c|c|c|c|c|}
\hline \multirow{2}{*}{ No } & \multirow{2}{*}{ Teacher name } & \multicolumn{2}{|c|}{ Performance Value } & \multirow{2}{*}{ Category } \\
\hline & & Indicator & Conversion & \\
\hline 1 & Hj Ernita setya wati, SE & 44 & 79 & Well \\
\hline 2 & Sajum Sutisna, ST & 43 & 77 & Well \\
\hline 3 & Tiara Panji Suhatno, S.Pd & 43 & 77 & Well \\
\hline 4 & Dra. Eny Hernawati & 43 & 77 & Well \\
\hline 5 & Esanuddin Nasution, $\mathrm{S} . \mathrm{Ag}$ & 44 & 79 & Well \\
\hline 6 & Iwan Suhendar, ST & 40 & 71 & Enough \\
\hline 7 & Diah Puspitasari, S.Pd & 42 & 75 & Enough \\
\hline 8 & Tati Kartini, S. Pd & 39 & 70 & Enough \\
\hline 9 & Dra. $\mathrm{Hj}$. Anissa Andromeda & 43 & 77 & Well \\
\hline 10 & Ngadiyo, SE & 42 & 75 & Enough \\
\hline 11 & Dwi Indhah Yuliastuty, S.Pd & 40 & 71 & Enough \\
\hline 12 & Wawan Priyadi, S. Kom & 40 & 71 & Enough \\
\hline 13 & M. Subhan, S. Pdi & 39 & 70 & Enough \\
\hline 14 & H. Andriansyah, S.Pd & 43 & 77 & Well \\
\hline 15 & Ellin Amelia, S.Si & 39 & 70 & Enough \\
\hline 16 & Tombus Sustenance, S.Pd & 40 & 71 & Enough \\
\hline 17 & Yudi Heryadi, ST & 39 & 70 & Enough \\
\hline 18 & Imam Muddin, ST & 42 & 75 & Enough \\
\hline 19 & Rini Irawati, SE & 40 & 71 & Enough \\
\hline 20 & Desti Musnita, S.Pd & 39 & 70 & Enough \\
\hline 21 & Elvi Susanti, S.Pd & 39 & 70 & Enough \\
\hline 22 & Fitri Aan Andriani, S, Pd & 39 & 70 & Enough \\
\hline
\end{tabular}




\begin{tabular}{|c|l|c|c|c|}
23 & Andi Widodo, S.Pd & 40 & 71 & Enough \\
\hline 24 & Nurdin, ST, MM & 44 & 79 & Well \\
\hline 25 & Sampurno, Amd & 42 & 75 & Enough \\
\hline 26 & Frans Harry Anggara & 39 & 70 & Enough \\
\hline 27 & Sudar, S.Pdi & 40 & 71 & Enough \\
\hline 28 & Supatmi, S. Ikom & 42 & 75 & Enough \\
\hline \hline 29 & Dina Anggraeni, SE & 42 & 75 & Enough \\
\hline 30 & Hanny, S. Kom & 40 & 71 & Enough \\
\hline 31 & Siti Jamilah, S.Pd & 40 & 71 & Enough \\
\hline 32 & Vika Khairunnisa, S.Pd & 42 & 75 & Enough \\
\hline 33 & Elly Anugraheni S, Amd & 40 & 71 & Enough \\
\hline 34 & Dimas nugra pratama, S.Pd & 39 & 70 & Enough \\
\hline 35 & Yulianah, S.Pd & 42 & 75 & Enough \\
\hline 36 & WahyudiHermawan, S.Pd & 40 & 71 & Enough \\
\hline 37 & Denny Setiawan, S.Pdi & 39 & 70 & Enough \\
\hline 38 & Dedi Lasdinar & 43 & 77 & Well \\
\hline 39 & Agus Helmi Meiyanto, S.pd & 42 & 75 & Enough \\
\hline 40 & Waldi Hifrodi, S.PdJas & 40 & 71 & Enough \\
\hline 41 & Ramadan Andriyanto & & & Enough \\
\hline 42 & Dean Novandi Sulaeman, SE & 42 & & \\
\hline
\end{tabular}

Source: Teacher Performance Assessment Instrument 2018/2019

From the data above, it can be concluded that there are some teachers who have poor historical records in terms of attendance and responsibilities in teaching, this shows the low performance of teachers at SMK Bina Pendidikan 3, in carrying out their work responsibilities.

Table 3 Factors influencing teacher performance at SMK Bina Pendidikan 3

\begin{tabular}{|l|c|}
\hline Factors Affecting Teacher's Performance & Results (\%) \\
\hline Leadership & 69.2 \\
\hline Motivation & 53.8 \\
\hline Compensation & 46.2 \\
\hline Competence & 30.8 \\
\hline Commitment & 53.8 \\
\hline Job satisfaction & 46.2 \\
\hline Work environment & 53.8 \\
\hline Means & 46.2 \\
\hline
\end{tabular}

Source Questionnaire googleform

Based on pre results The survey found that teacher performance at SMK Bina Pendidkan 3, Bogor was influenced by leadership factors $69.2 \%$, motivation $53.8 \%$ and commitment 53.8\%, leadership as a management concept according to Keith 1985 (Guterres, 2016:431) is the ability of a person to influence others in achieving goals with enthusiasm. According to Hasibuan 2007 (Guterres, 2016:431) leadership is the way a person leads to 
influence the behavior of his subordinates to want to work together and work productively to achieve organizational goals.

Based on previous research conducted by Luis Aparicio Gutrres, Wayan Gede Supartha 2016 shows that leadership style affects teacher performance at SMUN 02 Baucau positively and significantly. These results can be interpreted that the more precise the leadership style applied, the better the performance of the teachers. Teacher performance can be improved when teachers have better work motivation. Based on the results of the analysis, it can be seen that work motivation has a positive and significant effect on teacher performance.

Another research conducted by Reza Ahmadiansah 2016 shows that motivation and job satisfaction have a positive and significant effect on the performance of teachers at SMK Muhammadiyah Salatiga, it can be concluded that work motivation and job satisfaction have an influence on the emergence of teacher performance. Another study conducted by Listiana Kusuma Wardani showed that leadership, work motivation, organizational commitment had a significant effect on job satisfaction of Tegal City Junior High School teachers and leadership, work motivation and organizational commitment had a significant effect on performance through the intervening variable job satisfaction. Another study conducted by Bungawati et al 2016 showed that leadership, motivation, and discipline simultaneously affect performance.

Referring to the phenomena that the authors describe above as well as the previous research studied by the authors, it shows that there is no integrated research between leadership, work motivation, job satisfaction on teacher performance, so the authors are interested in analyzing the relationship between LEADERSHIP EFFECTS, AND MOTIVATION ON PERFORMANCE TEACHERS AND WORK COMMITMENTS AS INTERVENING VARIABLES

\section{LITERATURE REVIEW \\ Performance}

Performance appraisal requirements must meet certain measures or standards. This means that performance measures are carried out in accordance with performance indicators as measuring tools. According to Mitchell and Larson (1987:491) 'area of performance is quality of work, promptness, initiative, capability and communication'. This means that the area (indicator) of performance appraisal is the quality of work results, timeliness of completing work, initiative/initiative in completing work, ability to complete work, and communication/ability to foster cooperation with other parties.

Assessment of a teacher's performance is an important part of the whole process of the teacher's performance in question. According to Martinis Yamin and Maisah (2010;117-125) several sources of assessment for education personnel are: (1) self-assessment; (2) assessment by students; (3) peer assessment; and (4) assessment by direct supervisor. 


\section{Leadership}

Yulk (Fuadi 2014: 67) defines leadership as a process to influence, understand and agree with what needs to be done and how the task is carried out by leaders effectively, as well as a process to facilitate individuals and collectives to achieve common goals. Fuadi said that the leadership factor has a strong influence on building and increasing the productivity of subordinates. Leaders who know the characteristics of subordinates tend to be more trusted by subordinates, so that subordinates will follow all the rules and policies taken by the leader. In addition, the closeness of the leader with subordinates will further increase the confidence of subordinates to work optimally. Dubrin (Yunus 2013:171) provides a definition that leadership is an effort to influence many people through communication with instructions or orders, and actions that cause others to act and respond and cause positive change, an important dynamic force that motivates and coordinates organizations in achieving goals, the ability to create confidence and support among subordinates so that organizational goals can be achieved.

\section{Motivation}

According to Martoyo (Ahmadiansah 2016: 227) work motivation is something that gives rise to encouragement or enthusiasm for work, or in other words, driving morale. Robbins and Judge (Lestari 2015: 20) argue that motivation is a process that describes the integrity, direction, and persistence of efforts to achieve a goal. In this definition there are three key elements, namely: intensity, direction, and persistence. Intensity relates to how hard a person tries. Intensity can produce satisfactory performance if it is associated with a favorable direction for the organization. Efforts that are consistently directed towards organizational goals are the type of effort that should be made. Then the element of persistence is a measure of how long individuals can maintain their efforts Conducive and pleasant work motivation will provide work discipline for teachers in their work because teachers will feel comfortable in carrying out the tasks given. With a conducive work motivation will be able to generate discipline in carrying out their duties. This is in line with the opinion of Simamora (yenti 2015: 51) who stated that good work motivation is important for:

1. The creation of high work discipline

2. Generating work motivation.

3. Building the community towards the existence of the organization as a forum for potential development.

\section{Work Commitment}

Commitment is a form of individual or group behavior in an organization or institution. In relation to behavior, commitment can be interpreted as an attitude caused by a person or situation. The essence of work commitment is actually a willingness from within a teacher to make changes in behavior continuously in carrying out their duties. According to Hamzah B. Uno (2008:30) changes in behavior generally have several indicators: "1) there is responsibility in carrying out tasks, 2) the desire and desire to succeed, 3) the willingness and need in teaching, 4) there is a sense of home and pleasure towards work, 5) there is 
appreciation in teaching, 6) there is a sense of obligation and action in carrying out tasks. Teacher commitment to the organization is very important for the organization, to achieve the vision that has been set in the organization. Commitment is able to direct someone to devote themselves to the organization. Terence R. Mitchell and James R. Larson, (2005: 144) define commitment to the organization as a person's attitude to continue to participate in the organization. The factors of commitment to the organization, namely: (a) loyalty, (b) selfidentification with the organization, and (c) acceptance of organizational goals.

\section{Framework}

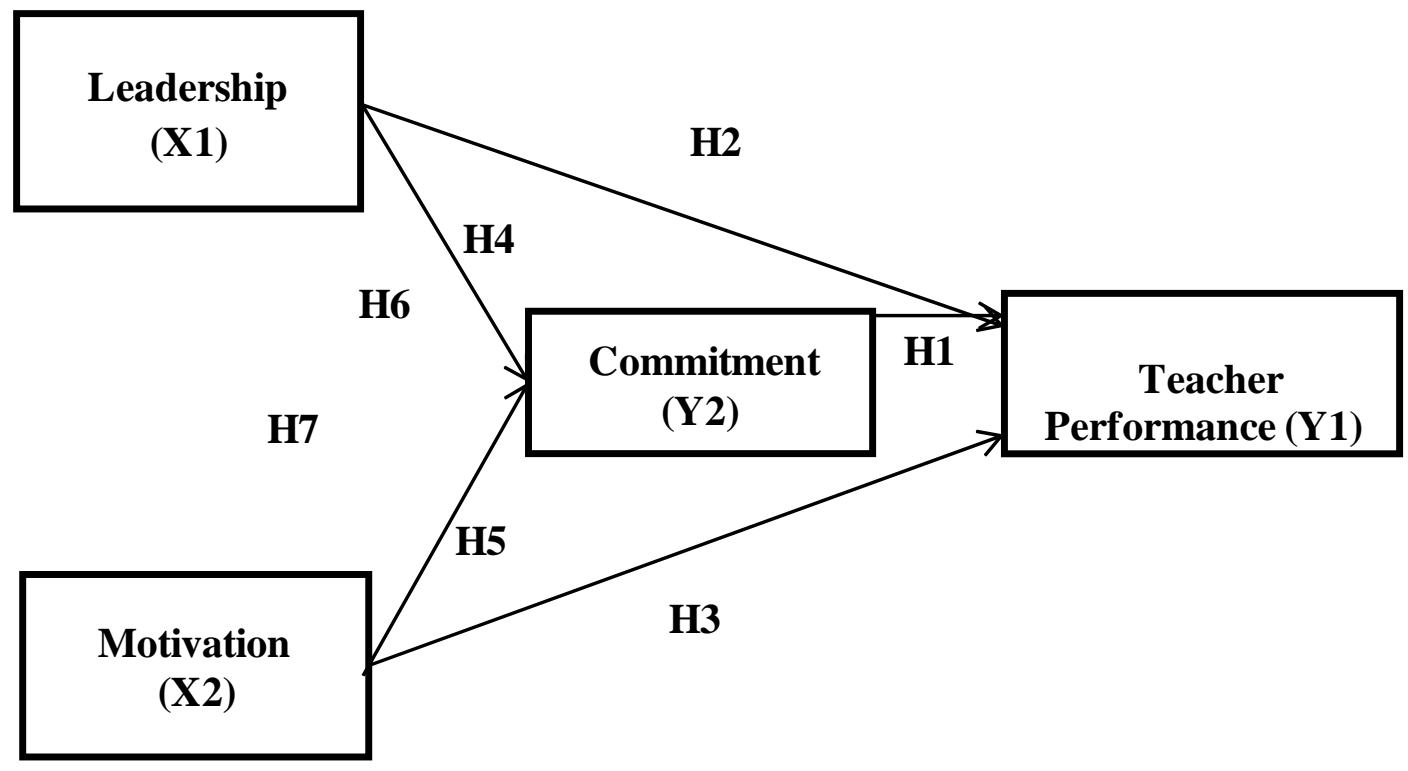

Figure 1. Framework

\section{Hypothesis}

H1: It is suspected that commitment has a positive and significant effect on performance Teacher

H2: It is suspected that leadership has a positive and significant effect on Teacher Performance

H3: It is suspected that motivation has a positive and significant effect on teacher performance.

H4: It is suspected that leadership has a positive and significant effect on Work Commitment.

H5: It is suspected that motivation has a positive and significant effect on commitment Work.

H6: It is suspected that leadership has an indirect effect on commitment and Teacher performance

$\mathrm{H} 7$ : It is suspected that motivation has an indirect effect on commitment and performance 


\section{RESEARCH METHOD}

\section{Types of research}

This type of research is explanatory, that is, the researcher tries to find the effect of the independent variables, namely the influence of leadership, motivation, and commitment on the influence of the related variable, namely the performance of the SMK Bina Pendidikan 3 teacher.

This casual explanatory research can be regarded as a hypothesis testing research that examines the causal relationship between variables that affect the hypothesis. This explanatory research method also aims to provide an overview/description in its description to produce a construct for a phenomenon based on knowing the relationship between several independent variables and related variables, followed by hypothesis testing (Sugiono, 2014).

The design used is a descriptive design with a quantitative approach and is carried out on the study of the influence of an independent variable (independent) on other variables (dependent). This research design is used to solve or answer the problems being faced in the current situation.

The next step is data collection, in this study using a survey method, with closed questionnaires using google forms, where respondents choose one of the answers that have been provided, with alternative answers consisting of 1-5 intervals on a Likert scale. The purpose of casual research in this case is to determine the effect of leadership, motivation and commitment on teacher performance.

\section{Operational Definition and Measurement of Variables}

\section{Operational Performance Variables}

Table 3.

\begin{tabular}{|c|c|c|c|}
\hline Variable & Dimension & Indicator & $\begin{array}{c}\text { Measurement } \\
\text { scale }\end{array}$ \\
\hline \multirow{13}{*}{$\begin{array}{l}\text { Teacher } \\
\text { Performance } \\
\text { Y1) }\end{array}$} & \multirow{4}{*}{ Work quality } & Preparation & \multirow{4}{*}{ Likert } \\
\hline & & Method & \\
\hline & & exercise & \\
\hline & & Facility & \\
\hline & \multirow{4}{*}{ Work result } & Target & \multirow{4}{*}{ Likert } \\
\hline & & Standard & \\
\hline & & Profession & \\
\hline & & Time Allocation & \\
\hline & \multirow{4}{*}{ Punctuality } & Program & \multirow{4}{*}{ Likert } \\
\hline & & Solution & \\
\hline & & Guidance & \\
\hline & & Forto Polio & \\
\hline & Presence & On time & Likert \\
\hline
\end{tabular}




\begin{tabular}{|l|l|l|l|}
\hline \multirow{2}{*}{} & Discipline & \multirow{2}{*}{} \\
\cline { 3 - 3 } & Managing time & \\
\cline { 3 - 3 } & \multirow{2}{*}{ Cooperation } & Communication & Likert \\
\cline { 3 - 3 } & & Can work together & \\
\hline
\end{tabular}

\section{Operational Variable Leadership}

Table 4

\begin{tabular}{|c|c|c|c|}
\hline Variable & Dimension & Indicator & $\begin{array}{c}\text { Measurement } \\
\text { scale }\end{array}$ \\
\hline \multirow{13}{*}{$\begin{array}{c}\text { Leadership ( } \\
\text { X1) }\end{array}$} & \multirow{4}{*}{ Task Oriented } & Plan and organize work & \multirow{4}{*}{ Likert } \\
\hline & & Coordinate activities & \\
\hline & & Provide what is needed & \\
\hline & & Setting work goals & \\
\hline & \multirow{6}{*}{ Relationship Oriented } & Trust and trust & \multirow{6}{*}{ Likert } \\
\hline & & Friendly and considerate & \\
\hline & & Develop and advance & \\
\hline & & Giving information & \\
\hline & & Appreciation of ideas & \\
\hline & & $\begin{array}{l}\text { Recognition of } \\
\text { contributions and success }\end{array}$ & \\
\hline & \multirow{3}{*}{ Participative } & $\begin{array}{l}\text { Guide and support } \\
\text { discussions }\end{array}$ & \multirow{3}{*}{ Likert } \\
\hline & & Constructive & \\
\hline & & Problem solving oriented & \\
\hline
\end{tabular}

\section{Operational Variable Motivation}

Table 5

\begin{tabular}{|c|c|c|c|}
\hline Variable & Dimension & Indicator & $\begin{array}{c}\text { Measurement } \\
\text { scale }\end{array}$ \\
\hline \multirow{6}{*}{$\begin{array}{l}\text { Motivation } \\
\text { (X2) }\end{array}$} & \multirow{3}{*}{$\begin{array}{l}\text { Motivation For } \\
\text { Achievement }\end{array}$} & Responsibility & \multirow{3}{*}{ Likert } \\
\hline & & Problem solving & \\
\hline & & Dare to take risks & \\
\hline & \multirow{3}{*}{$\begin{array}{l}\text { Motivation to } \\
\text { affiliate }\end{array}$} & Environment & \multirow{3}{*}{ Likert } \\
\hline & & Cooperation & \\
\hline & & award & \\
\hline & \multirow{3}{*}{ Motivation for power } & Social status & \multirow{3}{*}{ likert } \\
\hline & & Hard work & \\
\hline & & Don't harm others & \\
\hline
\end{tabular}

\section{Operational Work Commitment}

Table 6

\begin{tabular}{|c|c|c|c|}
\hline Variable & Dimension & Indicator & $\begin{array}{c}\text { Measurement } \\
\text { scale }\end{array}$ \\
\hline
\end{tabular}




\begin{tabular}{|c|l|l|c|}
\hline \multirow{4}{*}{$\begin{array}{c}\text { Commitment } \\
(Y 2)\end{array}$} & Identification & Trust & \multirow{2}{*}{ Likert } \\
\cline { 3 - 3 } & Aim & \\
\cline { 2 - 3 } & Involvement & Values & \multirow{2}{*}{ Likert } \\
\cline { 2 - 3 } & lill & \multirow{2}{*}{ Likert } \\
\cline { 2 - 3 } & loyalty & Work for the organization & \\
\cline { 2 - 3 } & & Stay organized & \\
\hline
\end{tabular}

\section{Population and Research Sample}

The population is a generalization area consisting of: objects/subjects that have certain quantities and characteristics set by the researcher to be studied and then draw conclusions (Sugiyono, 2016: 61). So the population is not only people, but also objects and other natural objects. The population is also not just the number of objects/subjects studied, but includes all the characteristic s/natures possessed by the subject or object under study. The population in this study were all teachers who were in SMK Bina Pendidikan 3 Kab. Bogor totals 42 teachers.

\section{Data analysis method}

In this study, the data analysis method used SmartPLS version 3.0 software using a computer. PLS is a component or variant-based Structural Equation Modeling (SEM) equation model. According to Ghozali (Yutevaa, 2010:75), PLS is an alternative approach that shifts from a covariance-based SEM approach to a variant-based approach. Covariancebased SEM generally tests causality/theory, while PLS is more of a predictive model. Besides being used to confirm theory, PLS can also be used to explain whether there is a relationship between latent variables. PLS can simultaneously analyze constructs formed with reflective and formative indicators. The choice of PLS is because the data does not have to be normally distributed multivariately, it can analyze as well as constructs made with many indicators.

\section{RESEARCH AND DISCUSSION \\ Descriptive Analysis}

Following are the results of the descriptive analysis of the variables of leadership, motivation, job satisfaction and teacher performance.

1. For the leadership variable, it can be seen that the statement that has the highest average (mean) of 4.619 with a standard deviation of 0.735 is the statement " The principal shows a friendly attitude when receiving input from the teacher" While the statement that has the lowest average value of 4.214 with a standard deviation of 0.764 is the statement " The principal cares about the problems experienced by the teacher" Based on the results above, it can be seen that the average respondent's response tend so agree with the statement in the questionnaire

2. For the motivation variable, it can be seen that the statement that has the highest average (mean) of 4.310 with a standard deviation of 0.795 is the statement "I was 
given the opportunity to attend training or seminars aimed at increasing my knowledge at work" While the statement that has the lowest average value of 3.905 with a standard deviation of 0.809 is the statement "I support each other and believe in myself in the field of work" Based on the results above, it can be seen that the average respondent's response tends to agree with the statement in the questionnaire

3. For the work commitment variable, it can be seen that the statement that has the highest average (mean) of 4.476 with a standard deviation of 0.856 is the statement "I am interested in making the name of the school famous with proud achievements prestasi" While the statement that has the lowest average value of 3.619 with a standard deviation of 0.779 is the statement "I want to keep working at this school because I believe it is difficult to adapt to a new school sekolah" Based on the results above, it can be seen that the average respondent's response tends to agree with the statement in the questionnaire

4. For the teacher performance variable, it can be seen that the statement that has the highest average (mean) of 4.690 with a standard deviation of 0.800 is the statement "I give enthusiasm and motivation to students in learning" While the statement that has the lowest average value of 4.357 with a standard deviation of 0.735 is the statement "I use a variety of assessment strategies and methods to monitor student progress and learning outcomes" Based on the results above, it can be seen that the average respondent's response tends to agree with the statement in the questionnaire

\section{Partial Least Square (PLS) analysis with SmartPLS V.3.0 . software}

The data analysis method using Partial Least Square (PLS) is a variance-based structural equation model. The evaluation of the PLS model is based on two basic evaluations, namely:

1. Measurement Model (Outer Model) Measurement evaluation (outer model) Partial Least Square is used to determine the validity and reliability of indicators measuring latent variables. The construct validity of the measurement model with reflective indicators can be tested by outer loading and using the Average Variance Extracted (AVE) parameter. Outer loading is used to test convergent validity and AVE is used to test discriminate validity. An indicator is said to be valid if the outer loading value is > 0.7 or can still be tolerated if it is above 0.5 and if it is below 0.5 it can be excluded from the analysis, besides that it can be measured by looking at the AVE value $>0.5$ (Ghazali, 2014:39 ). Meanwhile, to test reliability, it can be seen based on the Composite Reliability and Cronbach Alpha values from indicators that measure constructs.

2. Structural Model (Inner Model) Inner Model or Structural model aims to predict the relationship between latent variables or test hypotheses, the results of hypothesis testing are seen from the R-Squares value, changes in the R-Squares value can be used to explain the effect of certain exogenous latent variables on endogenous latent variables . Furthermore, a significance test was conducted to determine the effect between variables. The significance value used T-table at alpha 0.05 (5\%)

Figure 2. Path Coefficient results between variables 


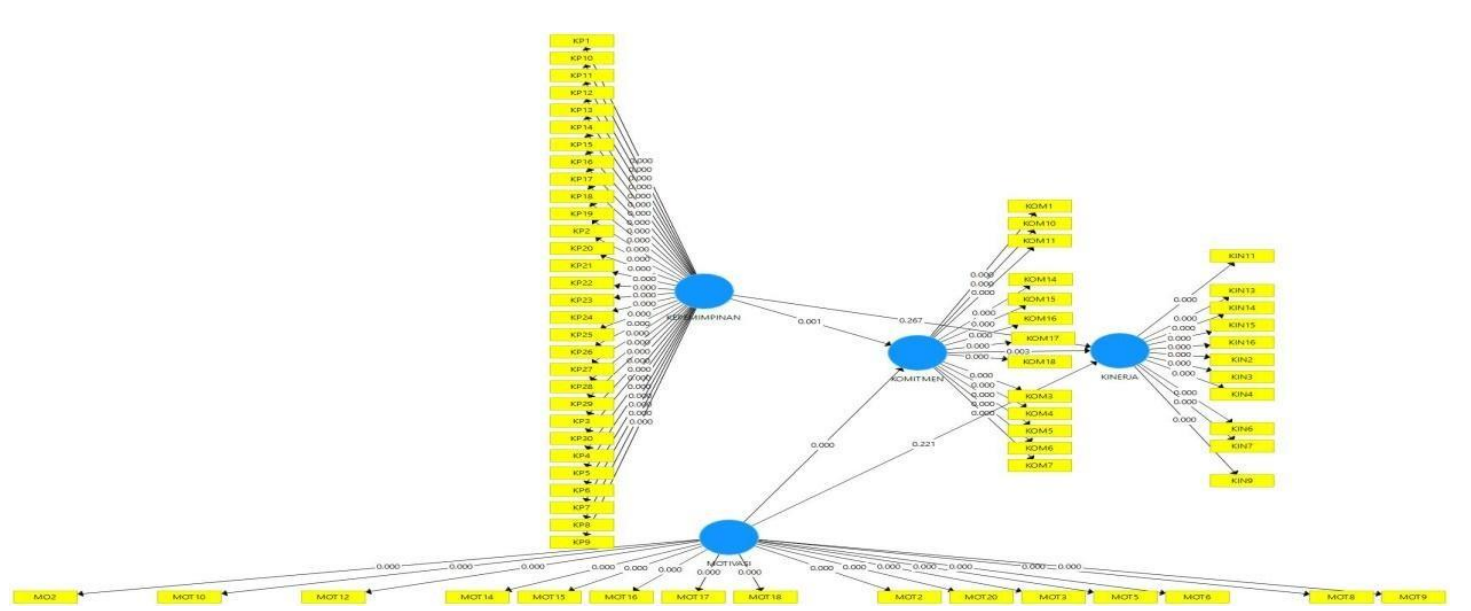

Figure 2.

Source: SmartPLS V.3.0 output output

\section{Composite Reliability Test Results and Cronbach Alpha}

Table 7

\begin{tabular}{|c|c|c|c|c|}
\hline \multirow{2}{*}{\multicolumn{2}{|c|}{$\begin{array}{l}\text { Crownbach's } \\
\text { Alpha }\end{array}$}} & & Composite & Information \\
\hline & & \multicolumn{3}{|c|}{ Reliability } \\
\hline Leadership & 0.975 & & 0.977 & Reliable \\
\hline Performance & & & 0.936 & Reliable \\
\hline Commitment & & 0.939 & 0.948 & Reliable \\
\hline Motivation & & 0.955 & 0.960 & Reliable \\
\hline
\end{tabular}

Dwhat can be seen from the above shows that the data is reliable because the test scores of Crwonbach's Alpha (CA) and Composite Reliability (CR) are already above 0.7. According to Cooper et al. in Joiyanto (2011) a valid construct is definitely a reliable construct. From the results of the SmartPLS 3.0 output, it can be concluded that the Composite and Crownbach's Alpha values have met the reliability test because they have reliability $>0.7$. This shows that the construct has good reliability or the questionnaire used as a tool in this study has been reliable or consistent.

\section{AVE Test Results (Average Variance Extracted)}

Table 8 Value of AVE

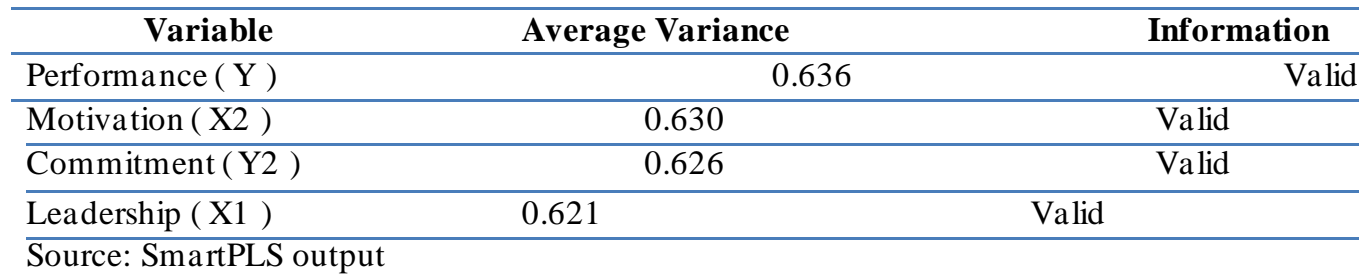

Can be seenThe AVE value of the leadership variable, motivation variable and teacher performance has a value above 0.60 , it shows that the leadership variable, commitment variable, motivation and teacher performance are valid. The AVE value is used as a condition 
for achieving discriminant validity (Wijayanto, 2008: 66). The minimum AVE value to state that reliability has been achieved is 0.05 (Wijayanto, 2008: 66). The AVE value below 0.50 indicates that the indicator has a higher average error rate. Thus, it can be said that the variable dimension has a value of $<0.05$.

\section{AVE Root and Correlation Between Constructs}

To find out the closeness of the relationship between the dimensions tested with latent variable correlations. This is presented in the following table:

Table 9 Latent Variable Correlations

\begin{tabular}{lccccc}
\hline \multicolumn{5}{c}{ Leadership Performance Commitment Motivation } \\
\hline Leadership & 1,000 & 0.730 & & 0.857 & 0.828 \\
Performance & 0.730 & 1,000 & & 0.809 & 0.617 \\
Commitment 0.857 & 0.809 & & 1,000 & 0.838 & \\
Motivation & 0.828 & 0.617 & & 0.838 & 1,000 \\
\hline Source: SmartPLS output & & & & &
\end{tabular}

Table 10 AVE values and AVE akar roots

\begin{tabular}{lcc}
\hline & $\begin{array}{c}\text { Average Variance } \\
\text { Extracted ( AVE ) }\end{array}$ & $\begin{array}{c}\text { Average Root } \\
\text { Variance Extracted (AVE) }\end{array}$ \\
\hline Performance & 0.636 & 0.946 \\
Motivation & 0.630 & 0.960 \\
Comtment & 0.626 & 0.948 \\
Leadership & 0.621 & 0.977 \\
\hline \multicolumn{2}{l}{ Source: SmartPLS output } &
\end{tabular}

The results of Latent Variable Correlations in table 4.15 and the AVE root in table 4.16 show that the AVE root is larger than the correlation between constructs.

\section{R-Square . Test Results}

R-Square testing is based on the results of research data processing using Smart PLS version 3.0. The inner model assessment criteria can be seen from the R-Square results, the greater the value means the greater the effect. Value (R2) aims to determine how much the independent variable affects the dependent variable. The value ( R2 ) can be seen in table 4.17 SmartPLS output results using calculate-PLS Algorithm as follows:

Table 11 R Square

\begin{tabular}{ll}
\hline & R Square \\
\hline Performance & 0.683 \\
\hline Sommitment & 0.787 \\
\hline
\end{tabular}

$\mathrm{R}$ square value $\left(R_{2}\right)$ of 0.683 means that the variability of the teacher's performance construct can be explained in this study of $68.3 \%$. The commitment in this study was $78.7 \%$. While the rest is explained by other variables not found in this study. 


\section{Hypothesis}

The following are the results of hypothesis testing obtained in the study through the inner model

Table 12 T Statistics and $P$ Values

\begin{tabular}{cll}
\hline Influence Hypothesis & \multicolumn{2}{c}{ T Statistics P Values Results } \\
\hline H1 & Commitment $\rightarrow$ teacher performance & 3,900 0.000 Received \\
H2 & Leadership $\rightarrow$ teacher performance 3,641 & $\mathbf{0 . 0 0 0}$ Dietrima \\
H3 & Motivation $\rightarrow$ Teacher performance & $0.198 \quad \mathbf{0 . 8 4 3}$ Rejected \\
H4 & Leadership $\rightarrow$ Commitment 3,620 & $\mathbf{0 . 0 0 0}$ Received \\
H5 & Motivation $\rightarrow$ Commitment & 2,632 0.009 Accepted \\
\hline
\end{tabular}

Source: Data processed by SmartPLS V.3.0 . output

1. H1, the Path coefficient value is known that the $P$ value that forms the effect of commitment on teacher performance is 0.000 where the result is $<0.5$. In addition, the $T$ statistic is 3.901 or $>1.96$. Thus it can be stated that commitment has a positive and significant effect on teacher performance. So the hypothesis which states that commitment has a positive effect on teacher performance is accepted.

2. H2, the value of the Path coefficient that forms leadership on teacher performance, the value of $\mathrm{T}$ statistic for leadership is 3,641. T statistic value > than 1.96 . While the $\mathrm{P}$ Values of 0.000 or $<0.5$. Thus it can be concluded that leadership has a positive and significant effect on teacher performance. So the hypothesis which states that leadership has a positive effect on teacher performance is accepted.

3. H3, the Path Coefficient value that forms the influence of motivation on teacher performance with a $\mathrm{T}$ statistic for motivation of 0.198 . The $\mathrm{T}$ statistic value is less than 1.96. While the $\mathrm{P}$ Values of 0.843 or $>0.5$. Thus it can be concluded that motivation has no significant effect on teacher performance. So the hypothesis which states that motivation has a positive and significant effect on teacher performance is rejected.

4. H4, the Path Coefficient value that forms the influence of leadership on the commitment of the $\mathrm{T}$ statistic for leadership is 3,620. The value of the $\mathrm{T}$ statistic is greater than 1.96. While the $\mathrm{P}$ Values of 0.000 or $<0.5$. Thus it can be concluded that leadership has a significant effect on commitment. So the hypothesis which states that leadership has a positive and significant effect on commitment is accepted.

5. H5, the Path Coefficient value that forms the influence of motivation on commitment, the $\mathrm{T}$ statistic for motivation is 2,632 . The value of the $\mathrm{T}$ statistic is greater than 1.96 . While the $\mathrm{P}$ values of 0.009 or $>0.5$. Thus it can be concluded that motivation has a significant effect on commitment. So the hypothesis which states that motivation has a positive and significant effect on motivation is accepted.

\section{Mean, STDEV, T-Values, P-values}

Table 13 Mean, STDEV, T. Values, P. Values

Influence Sample Mean STDEV T.Stsk P.Values

Leadership $\rightarrow$ Commitment $\rightarrow$ Performance 0.4320 .4810 .1882 .2940 .022

Motivation $\rightarrow$ Commitment $\rightarrow$ Performance $\quad 03430.3740 .1692 .0380 .042$

Source: Data processed by SmartPLS 2020 
Based on the results of the study, it was found that commitment intervened in the relationship between leadership and performance, with P.Values below 0.05, with a result of 0.022. And it was also found that commitment to intervening the relationship between motivation and performance with a P.Values value below 0.05 with a result of 0.042 , so commitment can be an intervening between the relationship between leadership and performance, as well as an intervening between motivation and performance.

\section{CONCLUSION}

1. Leadership has a positive and significant influence on teacher performance at SMK Bina Pendidikan 3. Bogor, this shows that good principal leadership can make teacher performance increase and be more productive

2. Commitment has a positive and significant effect on the performance of teachers at SMK Bina Pendidikan 3, Bogor, this shows that the more committed the organization is to teachers, the more the teacher's performance will improve.

3. Motivation does not have a significant effect on the performance of teachers at SMK Bina Pendidikan 3, Bogor. Because 33\% of respondents are over 30 years old, so the teachers of SMK Bina Pendidikan 3, are not motivated to improve performance, even though being given motivation has no effect on the performance of teachers at SMK Bina Pendidikan 3.

4. Leadership has a positive and significant influence on Teacher Commitment at SMK Bina Pendidikan 3, Bogor, this shows that if the leader is committed to what he leads, it will greatly affect performance.

5. Motivation has a positive and significant influence on Teacher Commitment at SMK Bina Pendidikan 3, Bogor, this shows that motivation with commitment to the road will affect teacher performance.

\section{REFERENCE}

Agus Susanto., Masydzulhak Djamil., Ahmad Badawi Saluy.(2021).

The Influence of Leadership, Performance Appraisal System, Work

Motivation on Job Satisfaction and Employee Perform PT PDSI. Proceedings of the 1st

MICOSS Mercu Buana International Conference on Social Sciences, MICOSS 2020, September 28-29, 2020, Jakarta, Indonesia.Vol,9. Page size: 10.25.50.Series CCER

Rka Verawati Journal of Economic and Economic Education Vol.4 No.2 (296-307) ISSN: 2302-1590 E-ISSN: 2460-190X.

Mohammad Aliakbari and Fatemeh Azimi Amoli

The Effects of Teacher Empowerment on Teacher Commitment and Student Achievement

ISSN 2039-2117 (online) ISSN 2039-9340 (print) Mediterranean Journal of Social Sciences MCSER

Publishing, Rome-Italy Vol 7 No 4 July 2016

Journal of Economy Culture and Society Effects of Servant Leadership on Gratitude, Empowerment, Innovativeness and Performance: Turkey Example, Journal of 
Economy Culture and Society 2018; 57: 29-52 Araştırma Makalesi / Research Article DOI: $10.26650 / \mathrm{JECS} 390903$

Journal of Technology Adjustment, Motivation for Retention and Environmental Similarity toward Satisfaction among Expatriate Academics Amir Parniana , Narges Hosseinia , Wong Shwu Fena* aFaculty of Management, Universiti Teknologi Malaysia, 81300 UTM Johor Bahru, Johor, Malaysia *Corresponding author: sfwong1984@ hotmail.com Journal of Raisah Surbakti Student Doctoral Program MP PPs Unimed EFFECT OF MOTIVATION, PERSONALITY, AND JOB SATISFACTION ON TEACHER COMMITMENT MAN 2 PADANGSIDIMPUAN

Ayu Kusumayani, Nyoman Natajaya, Bawa Atmadja e-Journal, Graduate Program, Ganesha University of Education, Education Administration Study Program (Volume 4 of 2013) CONTRIBUTIONS TO PRINCIPAL'S LEADERSHIP BEHAVIOR, TEACHER JOB SATISFACTION, AND TEACHER'S WORK COMMITMENT TO AMNEGERI CITY PERFORMANCE

Agus Anas Fuadi THE EFFECT OF LEADERSHIP, ORGANIZATIONAL CULTURE AND JOB SATISFACTION ON TEACHERS' WORK PRODUCTIVITY WITH ORGANIZATIONAL COMMITMENT AS MODERATING INFORMATION

September 2014 edition. Vol 1. No. 22337 - 5213

Titik Handayani, Aliyah A. Rasyid THE EFFECT OF SCHOOL PRINCIPAL LEADERSHIP, TEACHER MOTIVATION, AND ORGANIZATIONAL CULTURE ON TEACHER PERFORMANCE WONOSOBO STATE HIGH SCHOOL

WONOSOBO Journal of Education Management Accountability Volume 3, No 2, September 2015 (264-277)

Greenleaf, Robert K. The Servant as Leader. Published in Group \& Organization Management 31:3 (June 2006), pp. 300-326.

Haris Ngalimun and Alpha, 2013. The Development and Development of Creativity, Yogyakarta: Aswaja Pressindo.

Irving, JA 2005. Servant leadership and the effectiveness of teams. Dissertation of Doctor of Philosophy in Organizational Leadership, School of Leadership Studies, Regent University.

Kreitner, R. and A. Kinicki. 2010. Organizational Behavior. New York: McGraw-Hill. Luthans, Fred. 2011. Organizational Behavior: An Evidence-Based Approach. New York: McGraw-Hill.

Patterson, KA (2003). Servant Leadership: A theoretical model. Dissertation Abstract International, 64 (02),570. (UMI No. 3082719).

Podsakoff, PM, MacKenzie, SB, Paine, JB and Bachrach, DG 2000, "Organizational citizenship behaviors: a critical review of the theoretical and empirical literature and suggestions for future research", Journal of Management, Vol. 26 No. 3, pp. 513-563.

Robbins, Stephen and Timothy A. Judge. 2008. Organizational Behavior Edition 12, book 12, book 2. Jakarta: Salemba Empat Publishers.

Samira Mirshekar and Ebrahim Haddadi. Explaining the Role of Servant Leadership on Strengthening the Organizational Citizenship Behavior.International Research Journal of Finance and Economics. ISSN 1450-2887 Issue 161 May, 2017, pp 72-80. 
Sendjaya, S., Sarros, JC, \& Santora, JC 2008. Defining and measuring servant leadership behavior in organizations. Journal of Management Studies, 45(2), 402-424.

Soewarto Hardhienata. 2017. The Development Of Scientific Identification Theory to Conduct Operation Research in Education Management. IOP Conference Series: Materials Science and Engineering.

Spears, LC (2010). The character and servant leadership: Ten characteristics of effective, caring leaders. Journal of Virtues \& Leadership, 1(1), 25-30.

Stone, AG, Russell, RF, \& Patteerson, K. 2004. Transformational versus servant leadership. A difference in leader focus. The Leadership \& Organizational Development Journal, 25(4), 349-361.

Sugiyono.2007. Business Research Methodology. Jakarta: PT. grammar.

Supardi. 2013. Application of Statistics in More Comprehensive Statistical Concept Research. Jakarta: Change Publication.

Sutrisno Hadi. Statistics 2. Yogyakarta : Andi Offset, 2000.

Trompenaars, Fons and Voerman, Ed. 2009. Servant Leadership Across Cultures: Harnessing the strength of the world's most powerful leadership philosophy. New York: Infinite Ideas Limited.

Van Dyne, L., Cummings, LL, \& Parks, JM 1995. Extra-role behaviors: In pursuit of construct and definitional clarity (a bridge over muddied waters). In BM Staw \& L. Cummings (Eds.) Research in Organizational Behavior. Greenwich, CT: JAI Press Inc.

Yubo Hou, Ge Gao, Fei Wang, Tingrui Ri, and Zhilan Yu. Organizational Commitment and Creativity. Annals of Economics and Finance, Vol. 12 (2), 2011, pp. 411-431.

International Journal of Innovation, Management and Technology, Vol. 3, No. 5, October 2012, The Influence of Transformational Leadership and Organizational

Commitment on Job Satisfaction and Employee Performance

Journal of Industrial Engineering \& Management Research (JIEMAR) Volume 1 No 1 June 2020 E-ISSN: XXXX-XXXX

Leadership, Work Motivation, Competency, Commitment and Culture: Which Influences The Performance of Quality Management System in Automotive Industry?

ISSN 2039-2117 (online) ISSN 2039-9340 (print) Mediterranean Journal of Social Sciences

MCSER Publishing, Rome-Italy Vol 7 No 4 July 2016

The Effects of Teacher Empowerment on Teacher Commitment and Student Achievement

Septi Andriani, Nila Kesumawati, Muhammad Kristiawan, International Journal Of Scientific \& Technology Research Volume 7, Issue 7, July 2018, ISSN 2277-8616

The Influence Of The Transformational Leadership And Work Motivation On Teachers Performance

Anwar Sewang, International Journal of Management and Administrative Sciences (IJMAS) (ISSN: 2225-7225) Vol. 3, No. 05, (08-22)

The Influence of Leadership Style, Organizational Culture, and Motivation on the Job Satisfaction and Lecturer's Performance at College of Darud Dakwah Wal Irsyad (DDI) at West Sulawesi

Ahmad Handoko, Indi Djastuti ISSN (Online): 2337-3792 Volume 4, Number 4, 2015 
The Effect of Transformational Leadership and Work Motivation on Employee Performance with Job Satisfaction as an Intervening Variable (Study at Pt. Kereta Api Indonesia (Persero) Daop 4 Semarang 